Acta Horticulturae et Regiotecturae 1

Nitra, Slovaca Universitas Agriculturae Nitriae, 2019, pp. 37-40

\title{
ASSESSMENT OF SMALL SACRAL OBJECTS IN THE SENICA REGION, SLOVAKIA
}

\author{
Mária BIHUŇOVÁ*, Adrián MICHALICA \\ Slovak University of Agriculture in Nitra, Slovakia
}

\begin{abstract}
The sacral objects have great meaning in the cultural landscape in Slovakia. There are several types according to the significance, size and location, which could be identified in the countries, where the major religion is Christianity. The paper deals with the assessment of the sacral objects from architectural and urban point of view and also according to the presence of greenery accompanying the object. The surveyed area was the Senica region, located in the western part of Slovakia. The hidden symbolism and meaning of these objects could be find in their formation and precise placement. The greenery, which was planted by them the type and number - has also significant meaning. The group of trees draws attention to a small sacral object, which could be noticed from distance, they protect it and support it. There are descriptions and explanations in stories and memories. Obviously, in the past, these objects did not have only symbolic meaning, but also a concrete spiritual significance for society. The field survey was carried out in 2017. Several criteria were evaluated: the location of the objects, the architectural background and the trees inventory.
\end{abstract}

Keywords: small sacral objects, cultural landscape, Senica, Slovakia, assessment of greenery

In Slovakia, Christianity dominates, which results in a significant occurrence of sacral architecture and Christian elements in the landscape, in both urban and rural areas. The sacral objects have an important liturgical function. They have not been created in random places, but in the places that play important roles in the human life and everyday rituals of the local population. During the development of the society there were changes in the used materials, shapes, proportions and decorative elements (Kopeček a i., 2015). The main reason for building the objects of small sacral architecture was human belief that the patrons, who were figured, would protect them. For example, placing such objects on bridges, by streams or lakes, meant faith in protection against natural disasters. Sacral objects built at road intersections should protect the people against the evil and the dangers (Lukáčová, 1996). Sacral objects were also often built as a commendation or as a monument (Rozehnálová et al., 1995).

Small sacral objects are represented by: chapels, sculpture(s), crosses, wayside shrines, bell towers, column, etc. The spiritual memory of the place is emphasized by the placement of any religious object/picture/symbol. The place where the small sacral objects were built, had a special meaning. Besides religious significance (a place of thanks and prayers), it was also a memorial to the natural disaster and human tragedy or any significant historical incident. The builders left certain testimonies about the lives of people of that time (Košík, 1996).

Felberová (2003) points out that in the past, the main function of sacral objects was to promote and demonstrate Christian religion and to highlight the values of life.
The other functions are: border landmarks, localization points, authentic art sculpture. Nowadays, we can say that these places also have a high aesthetical, landscaping, orientational and recreational function.

Small sacral object is a type of a small building that does not have a residential function. It is located inside or outside an urbanised area or in the open landscape. It represents a religious object with no big scale (Rozehnálová et al., 1995; Kopeček a i., 2015).

Crosses are probably the oldest objects belonging to small sacral architecture. They have appeared since around $9^{\text {th }}$ century. The original crosses were wooden, at the end of Middle Ages they were made of stones. Iron forged crosses appeared in the $15^{\text {th }}$ century and from the $18^{\text {th }}$ century cast iron crosses on a pedestal with a crucified Christ were constructed (Kyselka, 2001). The history of raising up the crosses by the roads, cross-roads and in the peri urban areas is linked to the time of Christianity acceptance in the Slovak territory. The people had respect and fear of cross-roads in the past, so the cross built on the crossroad symbolized the protection from the dark forces. Crosses that were built in the field and by the road could have a grateful, apologetic or protective meaning (Nádaská, 2013).

The wayside shrines are usually in the form of a column, built from stone or brick. They could also have the shape of quadruple walled and carved pillar with a heel, shaft and head. On the top there is a case in which there is a painting (picture of a saint), a sculpture of a saint or embossment. There is often a shelter and a cross at the top. The wayside shrines are a type of chapels. They were built from $15^{\text {th }}$ to $19^{\text {th }}$ century in Slovakia (Botík and Slavkovský, 1995). 
The sculpture(s) of saints were placed in the boundaries, fields and by the paths on stone or concrete bases. They were 1-2 meters high. The statues were made of wood or stone and were painted. There is a huge range of saints figured. In the small chapel or wayside shrines there used to be placed: St. Joseph with the Baby Child, St. John of Nepomuk, St. Anthony of Padua, St. Mary Magdalene, St. Wendelin, Archangel Michael, St. Christopher, Guardian Angels, St. Anna, St. Catharine, St. Barbara, St. Urban. Particular attention was paid to the statues of Holy Mary and the Pieta. Most often they were made of sandstone. Sculptors were mostly unknown (Buganová et al., 2005).

Column - Marian pillars occur most often as for columns, followed by plague columns and Trinity columns. They were built due to belief of protection against disasters and diseases, or as type of gratefulness for ended of the worse (heavier) periods. The plague columns are widespread and significant type of small sacral objects. These columns originated mainly during the black death epidemics (Križanová, 1995).

Chapels are the youngest type of small sacral objects, dating back to the $17^{\text {th }}$ century. The symbolism plays significant role based not only in the architectonical design of a chapel, but also in the chosen place of location. The older chapels are with niches, where a painting or a statue of a saint was placed. The other, newer chapels are larger, and accessible to come in.

Bell towers were mainly located in urbanised areas of villages and cities and were used when the fire danger has appeared.

The inherent part of sacral objects is greenery. Many authors point to the symbolism hidden behind the planting of tree species by the objects. For example, Buganová et al. (2005) describes how and why these trees were planted. Usually the trees were purposely placed on four geographical sides (North, South, West and East). Sobotka (1879) studied the symbolism of the individual species of trees which were planted by the objects of the small sacral architecture.

At the beginning, only deciduous trees were planted by the sacral objects, because the Slavs have attributed them many symbolic aspects. The coniferous trees have appeared by the sacral objects only during the inter-war period. The reason for planting of evergreen woody plants was, that they remain green even during the winter period and their maintenance is less demanding and simpler than in the other types of greenery (Buganová et al., 2005).

\section{Material and methods}

The first written reference on Senica appeared in 1256 in documents by the King Bela IV. The original and first name of Senica was Scinze. By centuries, the name of the town evolved and changed and finally in 1920 the name Senica was used. Nowadays, Senica is a town with approximately 21,000 inhabitants. The district of Senica is rich in folk traditions, whether in the form of folk costumes, carpentry, chicory, blacksmithing and other crafts. Also, the ceramics of Sekul is world-famous in its colour (the colour of sand). (Garbierova et al., 2001) The Haban culture brought new insights and knowledge into the craft, the economy and the land use of the society. Before the Haban have appeared, the land and estates were devastated and burned by the Hussites. The industrial expansion and many reforms were secured by the government of Maria Theresa and Joseph II. The Senica region is rich in all types of the small sacral architecture objects: crosses, chapels, sculptures, columns, wayside shrines, columns.

The aim of the research was to evaluate and register all existing objects of small sacral architecture in the Senica region. The assessment has consisted of a field survey, following previous map data studying, websites of villages and towns and reading the relevant publications. Architectural assessment was completed by the inventory of greenery. The results were recorded in the tables and graphically processed in the posters.

\section{Evaluation of small sacral objects}

The following data were evaluated:

- serial number;

- localization (intravilan/extravilan);

- type of a monument: cross, wayside shrine, chapel, statue(s), bell tower, etc.;

- the year of origin;

- accompanying greenery: the number of accompanying trees, and their specification: deciduous trees, coniferous trees, shrubs;

- sccessibility or inaccessibility: The possibility to get to the object. In the case of chapels, it was possible to enter the object either anytime or only during special events;

- dimensions of the objects: in meters. Chapels and bells were specified by height $\times$ width $\times$ length. The height was specified in other types of objects. Current state of the monument: Range of damage was determined by the visual analysis in the following scale: Damaged up to $30 \%$, Damaged between 30-70\%, Damaged over 70\%, Restored. Material: The material the small sacral object was made of was specified.

The accompanying greenery was inventoried according to the methodology of Machovec (1982), Juhásova (1990) and Pejchal (1997) published in Supuka, Feriancová et al. (2008).

\section{Results and discussion}

Based on the field research we have found that $79 \%$ of the mapped small sacral objects were located in the urban environment of the towns or villages and only $21 \%$ were located in the open landscape. There were assessed 181 units of small sacral objects in total, spread in 31 cadastral areas of towns and villages. In the Senica region, crosses dominate ( $41 \%$ of the objects), $28 \%$ was represented by statue of a saint or sculptures of saints, $15 \%$ of all objects were chapels, $6 \%$ wayside shrines, $5 \%$ statues of Pieta, $3 \%$ of bell towers and $2 \%$ was represented by Calvaries.

St. John of Nepomuk, St. Florian and also the Virgin Mary have been figured on the statues. Statues of the Holy Trinity and Pieta could also be seen. 
Table 1 An example of small sacral objects assessment

\begin{tabular}{|c|c|c|c|c|c|c|c|c|c|c|c|c|c|}
\hline \multirow[t]{2}{*}{ No. } & \multirow[t]{2}{*}{ Type } & \multirow[t]{2}{*}{$\begin{array}{c}\text { Year } \\
\text { of } \\
\text { origin }\end{array}$} & \multicolumn{3}{|c|}{$\begin{array}{c}\text { Greenery } \\
\text { (numb. of } \\
\text { trees) }\end{array}$} & \multirow{2}{*}{ 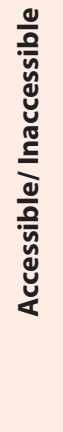 } & \multirow{2}{*}{ 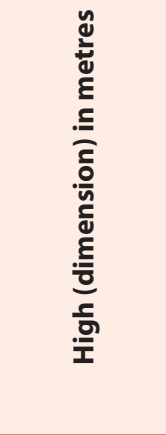 } & \multicolumn{4}{|c|}{ Condition } & \multirow[t]{2}{*}{$\begin{array}{l}\bar{\pi} \\
\frac{\pi}{2} \\
\stackrel{\pi}{\pi} \\
\sum\end{array}$} & \multirow{2}{*}{ 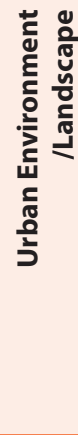 } \\
\hline & & & $\begin{array}{l}\frac{n}{0} \\
\frac{0}{0} \\
\frac{0}{2} \\
\frac{0}{0}\end{array}$ & 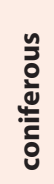 & $\begin{array}{l}\frac{0}{7} \\
\frac{2}{n}\end{array}$ & & & 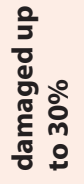 & 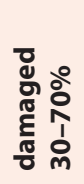 & 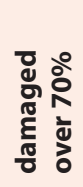 & 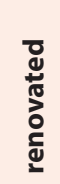 & & \\
\hline \multicolumn{14}{|c|}{ Kúty (village) } \\
\hline 1 & cross & - & 0 & 0 & 0 & $P$ & 4 & $x$ & & & & metal & UE \\
\hline 2 & cross & 1906 & 2 & 0 & 0 & $P$ & 2.4 & $x$ & & & & concrete & UE \\
\hline 3 & cross & 1898 & 0 & 1 & 0 & $P$ & 4.5 & $\mathrm{x}$ & & & & concrete & UE \\
\hline 4 & sculptural group & 1893 & 0 & 0 & 0 & $P$ & 3.5 & $x$ & & & & concrete & UE \\
\hline 5 & calvary & - & 4 & 2 & 0 & $\mathrm{P}$ & $2.5(x 14)$ & $x$ & & & & concrete & UE \\
\hline 6 & sculpture of Virgin Mary & - & 0 & 1 & 0 & $\mathrm{P}$ & 3.5 & $x$ & & & & concrete & UE \\
\hline 7 & chapel of St. Anna & 1852 & 0 & 0 & 0 & $\mathrm{~N}$ & $3.4 \times 4 \times 4$ & & $\mathrm{x}$ & & & concrete & UE \\
\hline 8 & belfry & 1826 & 0 & 1 & 4 & $\mathrm{~N}$ & $3.3 \times 3,3 \times 8$ & & & $x$ & & concrete & UE \\
\hline 9 & cross & 1850 & 0 & 1 & 4 & $P$ & 4 & $x$ & & & & concrete & UE \\
\hline
\end{tabular}

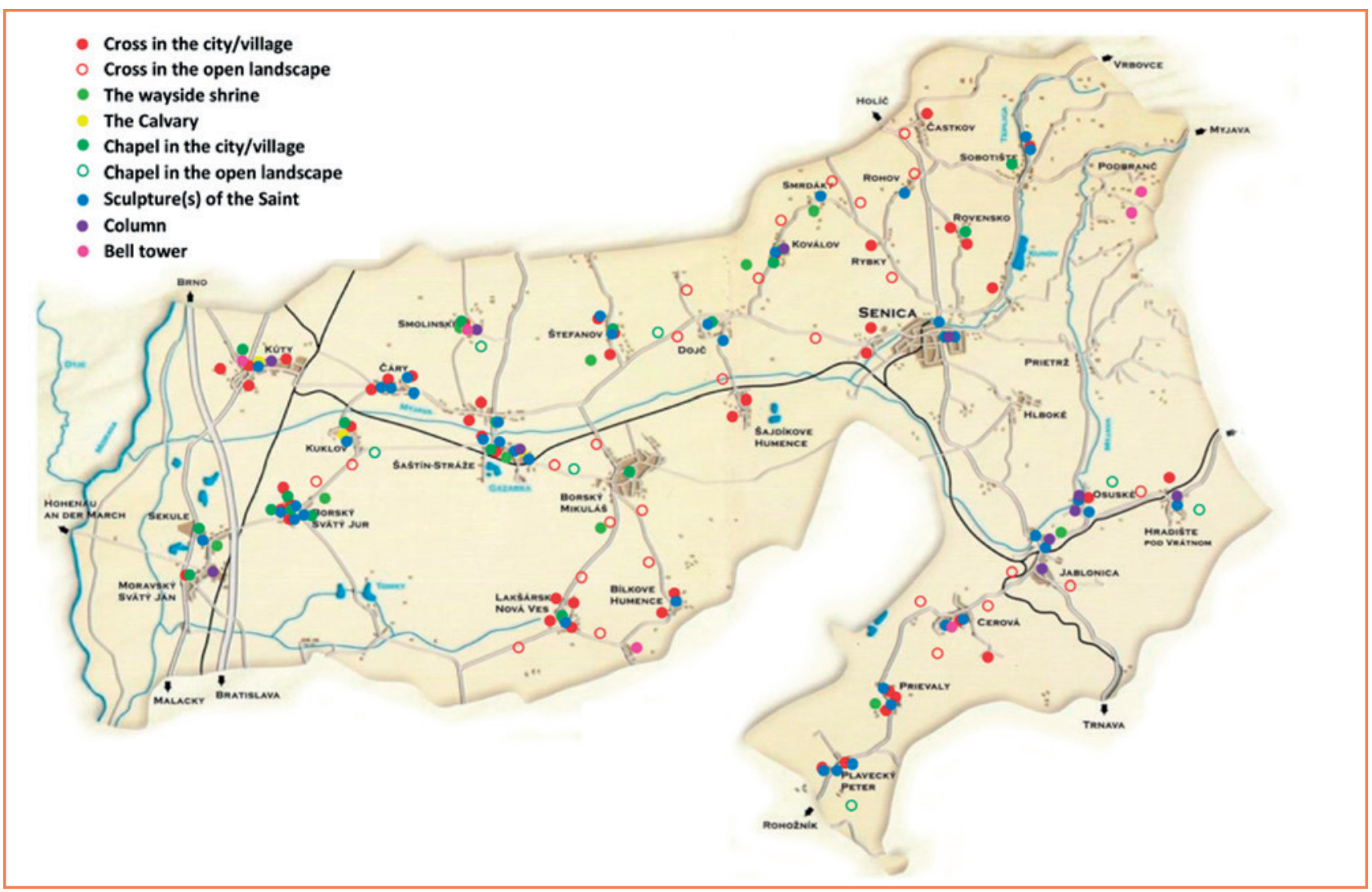

Figure 1 Localisation of assessed small sacral objects in the Senica region Source: Michalica, 2017 
Most of the chapels were dedicated to the Virgin Mary. We could suggest that the reason of great number of the small sacral objects dedicated to the Holy Mary is due to close location of Šaštín-Stráže, which is called the National Shrine of Slovakia. The one of the most important basilicas in Slovakia was built there, because of the statue of the Virgin Mary of Seven Sorrows from 1564. After the canonical examination, the statue was declared to be miraculous, confirmed by the Pope Urban VIII. In 1736 the church and monastery were built in the town. In 1764, the church was consecrated at the presence of the Empress Maria Theresa and Emperor Francis I. of Lorraine.

Renovated small sacral objects form $36 \%$ of all evaluated units. $34 \%$ of all mapped objects were damaged by $30 \%$. $23 \%$ of the objects were damaged in the range of $30 \%$ to $70 \%$. Objects damaged in more than $70 \%$ represent $7 \%$ of the total. Many renovations of small sacral objects were performed and according to the interviews and dialogues with locals, we have found out that many renovations are prepared in the near future.

Based on the field survey in 2017 and the detailed inventory of the trees, we have recorded 244 pieces of woody plants. Small sacral objects were mostly accompanied by deciduous trees, which is $84 \%$ of all trees. Coniferous trees represented $11 \%$ of the inventories species and $5 \%$ belongs to the shrubs. The most represented species is Aesculus hippocastanum L. (45\%) and on the second place there is Tilia cordata Mill. 36\%. Cerasus avium Moench., Acer pseudoplatanus L., Syringa vulgaris L., Sophora japonica L., Fraxinus excelsior L. occurred occasionally.

Thuja occidentalis L. represents the biggest group of coniferous trees inventoried. The other occurring species were Picea abies L. (16\%), Platycladus orientalis L. (16\%), Picea glauca Voss. (13\%), Taxus baccata L. (11\%), Pinus nigra Arn. (10\%), Juniperus communis L. (10\%), Pinus silvestris L. (3\%), Abies alba Mill. (3\%).

\section{Conclusion}

The landscape is created and modified not only by natural processes, but also by human activities. Society cultivates and enriches the environment which it is identified with and perceives it as a part of life. (Kopeček et al., 2015) Small sacral objects have been and always will be parts of our cultural landscapes. Every one of them has its own history and message. They are important elements, reminding of historical and cultural development, values and religious background of the society. Small sacral objects are integral parts of our landscape and could create the genius loci of the place. They are mainly related to the belief of people. Respect and peace is what these objects bring. It is important to pay attention to them also in the present time and consider them as a cultural heritage on the national and regional level.

The research of small sacral objects is supported by the VEGA project 1/0371/18 SacralArch: Preservation of the Historical Legacy and Architectural Diversity of Small Sacral Structures in Cultural Landscapes of Slovakia, where the regions of Upper Hron, Spiš, Nitra and Podpolanie have been mapped.

\section{Acknowledgement}

This paper is an outcome of research projects KEGA 011SPU4/2019; VEGA 1/0371/18; KEGA 024SPU-4/2019.

\section{References}

BOTÍK, J. - SLAVKOVSKÝ, P. 1995. Encyklopédia ludovej kultúry Slovenska 1. 1. vyd., Bratislava : Veda, 1995, 484 s. ISBN 80-224-0234-6.

BUGANOVÁ, K. a i. 2005. Postavené roku Pána. Košice : Asprodecus, 2005. ISBN 80-89093-08-6.

FELBEROVÁ, M. 2003. Drobná sakrálna architektúra na strednom Spiši. Bratislava : Mladé letá, 2003. ISBN 978-80-85167-37-5.

GARBIEROVÁ, D. a i. 2001. Okres Senica. Reprodruck, 2001. ISBN 80-968597-0-6.

KRIŽANOVÁ, H. 1995. Pamiatky a múzeá. Bratislava : Pamiatkový ústav v Bratislave, 1995.

KYSELKA, I. 2001. Význam drobných krajinnýhc prvků, zkušenosti a jejich obnovou u nás i v zahraničí. In Tváŕ naší země - Krajina domova, 2001, s. 29-34. ISBN 80-86512-03-7.

LUKÁČOVÁ, E. a i. 1996. Sakrálna architektúra na Slovensku. Komárno, 1996, $206 \mathrm{s.}$

MICHALICA, A. 2017. Drobné sakrálne objekty v okrese Senica. Bakalárska práca. Nitra : SPU, 2017, 75 s. + attachments.

KOPEČEK, P. a i. 2015. Projevy křest’anské liturgie v kulturní krajině. Brno: Mendelu, 2015, 164 s. ISBN 978-80-7509-387-5.

KOŠíK, L. 1996. Z duchovného dedičstva Skalice. Bratislava : Reprografia, 1996. ISBN 80-85594-03-x.

NÁDASKÁ, K. 2013. Prícestné kríže a kaplnky, prejav viery našich predkov. In Katolícke noviny, 2013, č. 28. Dostupné na https:// old.katolickenoviny.sk/28-2013-pricestne-krize-a-kaplnky-prejavviery-nasich-predkov/ [13.1.2019]

ROZEHNÁLOVÁ, E. a i. 1995. Cirkevní stavby. Brno : ÚÚR, 1995. ISBN 80-85124-48-3.

SOBOTKA, P. 1879. Rostlinstvo a jeho význam v národních písních, pověstech, bájích, obřadech a pověrách slovanských. Praha: Matica česká, 1879.

SUPUKA, J. - FERIANCOVÁ, L. a i. 2008. Vegetačné štruktúry v sídlach - parky a záhrady. 1. vyd., Nitra : SPU, 2008. 504 s. ISBN 978-80-552-0067-5. 